\title{
CEO Career Concerns And Voluntary Disclosure
}

Soo Yeon Park, Korea University, South Korea Kwan Hee Yoo, Korea University, South Korea

\begin{abstract}
This paper investigates the relation between Chief Executive Officers (CEO) career concerns and voluntary disclosures using listed firm (KOSPI) data in Korea. Prior research suggests that explicit incentives in the form of CEO stock-based compensation or CEO's equity ownership mitigate the agency problems of reluctance to make voluntary disclosure. In addition, implicit incentives arising from CEO career concerns are as important as explicit incentives for mitigating agency problems.

The labor market assesses CEOs ability and CEO reputation in the market is a valuable asset that is associated with many long-term benefits, such as better future compensation, reappointment in the position, and greater managerial autonomy. CEOs are concerned about such an assessment and these concerns are referred to as career concerns. However, the market has incomplete information about CEOs' ability especially when the CEOs have short tenures as a CEO position. Hence, CEOs with short tenures have more strong incentives to signal their ability to the labor market so that they can build proper reputation.

Implicit incentives arising from CEO career concerns are measured by CEO tenure. I assume that short-tenured CEOs are more career-concerned than long-tenured CEOs. I find that CEOs with short tenures tend to more likely disclose management forecasts. I interpret this result that more career-concerned CEOs have strong incentives to signal their ability to the labor market in order to build their reputations which affect their future payoffs such as compensations and reappointment. In addition, management forecasts, means of voluntary disclosure, are used as effective mechanism. I also find that CEOs with short tenures tend to disclose more accurate management forecasts. This result implies that CEOs with more career concerns have more pressure to provide accurate forecasts because of their reliability in the labor market. Based on these empirical results, I infer that CEOs' implicit incentives affect their voluntary disclosure decision.
\end{abstract}

This study will contribute to academics and disclosure-related practitioners by documenting about CEOs' career concerns and their voluntary disclosure decisions.

Keywords: CEO Tenure; Career Concerns; Voluntary Disclosures; Management Forecasts

\section{INTRODUCTION}

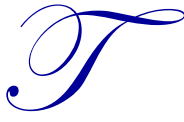

his paper provides an empirical analysis on how career concerns impact voluntary disclosure by Chief Executive Officers (CEOs) of Korea's publicly listed companies, with a view that career concerns are one of the major implicit incentives for the management. In particular, by using the CEO's job tenure as a proxy for their career concerns, I examined how career concerns influence the CEO's decision-making on voluntary disclosure and accuracy of forecast disclosure.

It should be noted that voluntary forecast disclosure allows internal information to be publicly available and thereby reduces information asymmetry between the management and outside investors in the market (Verrecchia 2001), eventually leading to increased corporate value, such as enhanced stock market liquidity and lower cost of capital (Diamond and Verrecchia 1991; Leuz and Verrecchia 2000). In addition, voluntary disclosure affects analyst earnings forecast (Waymire 1986) as well as share price in the stock market (Sohn 1997a, 1997b). In other words, along with 
mandatory reporting, voluntary management forecast acts as an essential intermediary to share information with investors and alleviate information asymmetry.

Unlike mandatory reporting that requires issuance of certain financial statements and annual report, the management has more discretion with voluntary disclosure, in terms of whether private information will be disclosed, which method to follow and how much scope of information will be disclosed. As voluntary forecast disclosure is primarily based on management's privately inferred information about future business operation, not only investors consider the disclosure timely and relevant for their investment decisions, it also resolves information asymmetry in the market.

That being said, the management may not be willing to make their privately inferred information publicly available, as they expect disclosure could potentially result in increased market discipline on their activities. By choosing not to disclose private information, the management can reduce the probability of being replaced (Shleifer and Vishny 1989) and prevent their managerial ability from uncertain assessment in the labor market (Nagar 1999). Under this circumstance, information asymmetry between the management and outside investors creates agency problems in which agents, i.e., the management, behave in an opportunistic manner at shareholder expense (Akerlof 1970). However, according to previous studies conducted on the matter of agency problems, certain explicit incentives such as stock option grants or equity ownership are proven effective in mitigating the problems and encouraging the management to disclose private information (Aboody and Kasznik 2000; Nagar et al. 2003).

Meanwhile, Gibbons and Murphy (1992) studied the impact of career concerns - concerns about how the management's current performance will affect future compensation and extension of tenure - on optimal incentive contract. They added optimal incentive contract to the Fama-Holmström model, and theoretically verified that both explicit (e.g., compensation contract) and implicit (e.g., career concerns) incentives are a solution to deal with agency problems.

Thus, when examining which factors encourage voluntary disclosure, it is vital to look at implicit incentives provided to those who are directly responsible for disclosure of information, not to mention to consider explicit incentives that help alleviate agency problems. In fact, it is expected that career concerns play an important role for voluntary disclosure because, after all, one of the purposes for information disclosure is to make a statement about managerial ability. Several studies show that information disclosed by the management has been useful references for determination of market value of a firm as well as management performance (Fama 1980; Nagar 1999; Verrecchia 2001). Yet little has been studied about how voluntary forecast disclosure is affected by implicit incentives of the management.

In 2007, in a survey of 112 Korean CEOs, it was reported that the average number of companies for which the CEOs have worked was 2.9 and the average length of time spent at one company was 4.8 years 1 . A few years later, another survey of CEOs at the 10 largest corporate groups in Korea indicated that the average tenure was merely 2.97 years, falling short of a maximum term of 3 years provided by the Commercial Act2. What is more, the length of tenure was less than two years at 14 companies out of 81 affiliates within the 10 largest corporate groups. The survey found that only four companies had the average tenure longer than 3-year limit: 4.3 years for LG, 3.7 years for Samsung, 3.1 years for Hyundai Heavy Industries and Hanhwa. While many dream of climbing to the top of the corporate ladder and achieving great wealth, power and prestige, this survey provides a glimpse of reality where becoming a CEO and keeping the position is never as easy as it sounds. To become CEOs, their expertise must be proven whether internally promoted or recruited from outside; then after becoming CEOs, they face constant pressures on their work and insecurity of their position. In this regard, it is only natural that CEOs are in absolute need of incentives which will effectively address their job insecurity and career concerns and, at the same time, signal their business performance and managerial ability to the labor market. And such incentives may differ from person to person depending on years spent at a company. Short-tenured CEOs are highly motivated to demonstrate management skills to investors, and as such, their career concerns are related to gaining trust from shareholders that could later translate into a good reputation

${ }^{1}$ Solution, an executive search firm, analyzed career data on 112 CEOs at local and global companies in Korea and found that the average number of companies for which the CEOs have worked was 2.9 and the average length of time spent at one company was 4.8 years. The number of years spent at the first company was 8.1 years (Financial News, April 24 2007).

${ }^{2}$ Kuki News, Kukmin Daily, 2012-10-10

Copyright by author(s); $\underline{\mathrm{CC}-\mathrm{BY}}$ 
in the labor market and higher compensation. Hence, it is not surprising that they are willing to take unobservable actions in order to influence the market's beliefs (Gibson and Murphy 1992). Of course, in employee position, they must have built a strong reputation and expertise has been well recognized, but once they take the CEO role, their capability needs to be assessed from a whole new different point of view. In this respect, short-tenured CEOs will focus on revealing more information on their managerial ability since acknowledgement in the market lays the foundation for higher monetary compensation and other non-monetary benefits such as extension of term, reappointment or promotion. Considering that both voluntary and mandatory disclosure are key channels to communicate and share information with outside investors, short-tenured CEOs are expected to take full advantage of voluntary disclosure for communication of earnings forecast as well as effective display of their managerial skills. On the other hand, long-tenured CEOs are less likely to signal their ability in the labor market since the market is already familiar with their business reputation and management performance. Especially when the average length of tenure is only 4.8 years, as explained above, CEOs who are reappointed after the expiration of 3-year term limit would be less motivated to prove themselves in the market compared to the CEOs in early years of tenure. In their mid to later years of tenure, CEOs would aim to respond to market's remaining doubts about their management ability and firmly establish positive business reputation. At this stage, they regard voluntary disclosure as an effective way to accomplish their goals. In a nutshell, the newer the management are, the more willing they are to use voluntary disclosure in a timely manner in order to dissuade uncertainties the market will have about CEOs' ability. In a survey of certain chief financial officers, Graham et al. (2005) argued that one of the main purposes of voluntary disclosure is to gain a solid reputation from investors, and suggested that there is a strong correlation between implicit incentives and voluntary disclosure.

Career concerns have a meaningful impact on recognition of CEOs' managerial ability in the labor market. That is, career concerns are a basis to predict potential increase in CEO's future compensation or possibility of promotion. In the labor market, performance outcome and stock prices have mostly been taken into account for evaluation of CEO's ability. In previous literature, it was suggested that management's career concerns would influence recognition of their ability in the market (Brickley et al. 1999; Dewatripoint et al. 1999; Fama 1980; Song and Thakor 2006).

In this paper, career concerns are presented as key incentives for voluntary disclosure. To be more specific, by using tenure years as a proxy for career concerns, I explored how career concerns affect voluntary disclosure and accuracy of such disclosure of management forecast. It is expected that CEOs with short tenure are more motivated to signal their managerial ability in the labor market to deal with market's uncertainties about their ability. In this regard, the relation between CEOs' tenures, i.e., career concerns, and voluntary disclosure was carefully examined.

To empirically investigate how tenures affect CEOs' decision on voluntary disclosure and accuracy of disclosure, I used data on diverse facts about a company - e.g., management tenure, company size, debt to equity ratio, price-tobook ratio, earning volatility - as well as explicit incentives such as availability of stock option program and equity ownership in 5,684 companies over the period November 2002 to 2011.

Firstly, the results of data analysis show that the shorter the tenure is - i.e., the bigger the career concerns are, the more eager the management are to disclose company forecast in a voluntary manner. Particularly, when the management have strong career concerns, they are highly likely to disclose information on sales revenue. This illustrates the fact that short-tenured management utilizes voluntary disclosure as key mechanism to form new expectations in the market and gain a reputation on their managerial ability.

Secondly, when errors in management forecast is used as a dependent variable in the analysis, a meaningful positive correlation is observed between tenure and errors in management forecast. In other words, the shorter the tenure is, the less discrepancy appeared between forecast and actual information, resulting in more accurate and reliable disclosure. Naturally, inaccurate and unreliable disclosure comes with an opportunity cost - i.e., when a forecast turns out to be too different from actual numbers, investors leave with negative impression about management credibility and in worst cases, the company could face decrease in stock prices, damage to management reputation or risks for a shareholder lawsuit. For this reason, CEOs with short tenure tend to ensure reliability of disclosure to better signal their ability. 
To add more robustness to my studies, additional analysis is conducted by taking into account self-selection bias problems and the impact of earnings management on forecast accuracy. Consistent with the previous results, the additional analysis also shows that short-tenured CEOs are more likely to disclose management forecast and accuracy of such disclosure increases as well.

This paper contributes to earlier literature in the following ways: first, most of the literature examined which factors affect management forecast and several concluded that implicit incentives such as career concerns - i.e., tenure - has significant impact on economic activities and behaviors by the management (Fama 1980; Gibbons and Murphy 1992; Holmstrom 1999). However, few conducted an empirical analysis to investigate relations between voluntary disclosure and tenure. In this paper, I analyzed whether and how career concerns motivate the management to use voluntary disclosure to resolve information asymmetry. With tenure as a proxy for implicit incentives, the analysis shows that such incentives play an important role for the management's decision-making on voluntary disclosure and accuracy of the disclosure. This provides meaningful insights into the importance of career concerns being a key factor for disclosure of management forecast.

Second, many have explored which incentives are in play for disclosure of forecast and accuracy of such forecast (Penman 1980; Waymire 1984; Lang and Lundholm 1993; Bamber and Cheon 1998) but they were limited to firmspecific and disclosure-specific characteristics. In this paper, I investigated a more fundamental driving force behind disclosure of accurate information by looking at the impact of implicit incentives, i.e., the management's tenure, on forecast disclosure.

Third, while the previous studies (Nagar et al. 2003; Aboody and Kaznik 2000) focused on explicit incentives for management forecast such as stock options, analysis in this paper centers on implicit incentives, for instance, career concerns in the form of management tenure. This paper contributes to the previous findings that another factor for voluntary disclosure is additionally discovered to explain the relation between management incentives and forecast disclosure.

Fourth, this paper provides an empirical analysis on how the reliability of voluntary disclosure is influenced by implicit incentives of the management. The analysis concludes that career concerns serve as a meaningful factor for better judgment of forecast information by outside investors in the market.

The rest of this paper is organized as follows. Section II provides review of previous literature and hypotheses used in the paper. Section III discusses analysis methodology, and Section IV describes the result of empirical analysis and its interpretation. Finally, Section V concludes with implications and limitations of the analysis.

\section{LITERATURE REVIEW AND HYPOTHESES DEVELOPMENT}

\subsection{Literature Review}

In this paper, I explored how implicit incentives influence managers' decision-making on voluntary forecast disclosure and accuracy of such forecast. Particularly, considering managers' tenure as a proxy for implicit incentives, an empirical analysis is provided to examine how implicit incentives in the form of career concerns impact disclosure behavior. The following is a literature review of this area, which is mainly in three topics: career concerns, motivations behind voluntary disclosure and accuracy of disclosure information.

\subsubsection{Career Concerns}

The labor market continuously adjusts its expectations on managers' ability by reflecting their performance records, and such expectations gradually form market perceptions that would affect monetary compensation and non-monetary benefits such as promotion (Gibbons and Murphy 1992). For this reason, it is only natural that managers are deeply interested in knowing how they are evaluated in the labor market and make efforts to ensure fair evaluation of their managerial skills. In other words, management behavior is driven by motivations to pursue higher compensation and 
build a strong business reputation as well as to influence existing market perceptions (Fama 1980; Gibbons and Murphy 1992; Brickley et al. 1999; Song and Thakor 2006).

Analysis by Fama (1980) is first to review career concerns in a way that he asserted career concerns alleviate agency problems arising between managers and shareholders. His theory was that implicit incentives, i.e., career concerns, are a sole motivation for managers to take better care of their companies and thus explicit contract incentives are not necessary. According to his analysis, good performance leads to an increase in future compensation while poor performance results in devaluation of business reputation. Therefore, the labor market functions properly with the help of optimal implicit incentive contracts, prompting managers to act in shareholders' interests. Holmstrom $(1982,1999)$ divided period of tenure into early stage and late stage, and investigated what kind of implicit incentives are in play during each stage. According to him, the younger the management are, the higher career concerns they seem to have: in early stage of tenure, young managers have high career concerns and are likely to avoid any chance of being assessed negatively, while managers in late stage of tenure tend to less prioritize such behavior.

Many empirical analyses in succeeding literature extended Fama and Holmstrom by identifying how career concerns affect a wide range of management economics. Gibbons and Murphy (1992) defined career concerns as concerns about how current performance would affect future compensation, and investigated the impact of career concerns on optimal incentive contracts. Their theoretical analysis showed that both explicit (e.g., compensation contract) and implicit (e.g., career concerns) incentives are required to yield the best performance.

Also, career concerns are known to influence managers' project choice and risk taking behavior (Shleifer and Vishny 1989; Coles et al. 2006; Chen and Zheng 2012). A recent empirical analysis by Chen and Zheng (2012) observed a meaningful positive correlation between tenure and risk taking; it provides a useful insight on managers' tendency to take more risks in later years with career concerns decreasing years go by.

There are other literature reviews that explored career concerns from an accounting perspective, for instance, earnings management or earnings quality. Graham et al. (2005) provided an evidence in which career concerns act as a motivation towards earnings management. They conducted a survey among 400 chief financial officers (CFOs) to find that more than $75 \%$ of the respondents saw attaining a better social position in the market more valuable than earning short-term monetary benefits. He argued that this proves implicit incentives are a crucial factor for earnings management, and pointed out previous studies had focused only on the impact of explicit incentives such as cash compensation. Demers and Wang (2010) extended Holmstrom to further analyze relationship between managers' career concerns and earnings management from a theoretical perspective. Their analysis suggested that long-tenured managers make earnings management through both accrual and real activities manipulation, compared to those with short tenure. On the contrary, an empirical analysis by Ali and Zhang (2012) on the subject of how managers manipulate earnings over the course of their tenure found that upward earnings management is prevalent for shorttenured managers. This finding means that managers in early years of tenure need to inflate earnings in order to signal their ability, but they move away from that behavior to prevent loss of reputation or dismissal. In his study of manager tenure and earnings quality, Zhang (2009) concluded that managers with long tenure report earnings less aggressively than those with short tenure, both in terms of conservative loss recognition and lower discretionary accruals. He interpreted this conclusion as suggesting short-tenured managers have motivations to manipulate earnings for the sake of their reputation.

Others discussed career concerns of specific professionals instead of general management. Chevalier and Ellison (1999) explained that young mutual fund managers have implicit incentives comparatively different from those of older managers, because they are more likely to be dismissed when their performance is not up to scratch and because they tend to behave more aggressively. It turned out young fund managers avoid unsystematic risk in selecting investment targets and come up with more conventional portfolio. In a similar analysis by Hong et al. (2000) on career concerns of financial analysts, less-experienced analysts are found to deviate less from consensus forecast, i.e., they herd more, and when deviation exists, they modify such deviation more frequently. This means career concerns are another important factor for herding behavior. 
As discussed above, career concerns have been analyzed from diverse perspectives, but little has been written from an accounting perspective and in particular, Korean CEOs' career concerns have rarely been looked at.

Healy and Palepu (2001) and Beyer et al. (2010) pointed out there are no studies conducted on the impact of career concerns on voluntary forecast disclosure. I view career concerns are expected to play an important role for managers' decision on voluntary disclosure since disclosure information tells of corporate value and managers' managerial ability to outside investors. In this respect, voluntary disclosure of forecast would be an effective tool for managers to signal their ability in the labor market and reduce uncertainties the market has about them.

Beyer and Dye (2012) explored how managers' reputational concerns affect their disclosure behavior. They developed a two-period model where managers either behave as forthcoming (i.e., disclose earnings forecast whenever they have it) or as strategic (i.e., discloses forecast only if it is in their self-interest). It turned out strategic managers see how disclosure of their earnings forecasts would affect their reputation as well as company's stock price. Managers who are more likely to be strategic in the future have a higher motivation to disclose a forecast today, and in addition, if reputation is at stake, they disclose more information compared to forthcoming managers. And in the case where investors become uncertain about managers' overall propensity to behave strategically in the future, managers are more likely to manage their reputations by issuing a forecast that decreases the current stock price.

\subsubsection{Motivations for Voluntary Forecast Disclosure}

One of the mainstreams in empirical research on voluntary disclosure is review of motivations for disclosure at potential expense arising from letting private information out in the market (Verrecchia 1983). Healy and Palepu (2001) and Bayer et al. (2010) used capital markets transactions, stock compensation, corporate control contest, litigation cost, management talent signaling and proprietary cost hypotheses to discuss reasons behind voluntary management forecast.

Trueman (1986) noted that management talent signaling hypothesis, among others, explains managers are motivated to signal their managerial ability through voluntary disclosure especially when the market is in doubt of their ability. Normally, corporate value depends on managers' ability to predict changes in future economic conditions and to adjust production plans based on predictions. As outside investors rarely have a first-hand experience of managers' ability and rely on mostly on disclosure information as relevant reference, they require timely information from managers. In his study, Trueman assumed capable managers are good at collecting private information in a timely manner, providing useful information in which changes in economic environment are adequately reflected. Baik et al. (2011) analyzed relationship between managerial ability and forecast disclosure by using media citations, data envelope analysis (DEA) and industry-adjusted return on asset as proxies for managers' ability. Their empirical analysis indicated that high managerial ability increases the likelihood and frequency of voluntary disclosure, and accuracy of disclosure improves in the hands of capable managers. As such, forecast disclosed by competent managers is regarded as an informative signal of their ability to predict future economic changes, compared to that made by not-socompetent managers. However, as Healy and Pelepu (2001) mentioned in their paper, there has been relatively little empirical research on management talent signaling hypothesis.

\subsubsection{Accuracy of Voluntary Forecast Disclosure}

Whether voluntary disclosure alleviates information asymmetry depends on the degree of credibility of information on company's economics, which is often not available from other sources including mandatory reporting (Healy and Palepu 2001). As explained earlier, credibility of information is not always guaranteed since managers may act for their own economic reasons.

Research on credibility of forecast disclosure has mainly been done in two areas: factors determining accuracy and precision of forecast. In this section, I am going to review previous research on forecast accuracy and move on to precision. 
Researchers compared voluntary disclosure to forecasts derived from random walk model or to analyst predictions to see if the former contains relatively accurate information than the latter. Earlier literature showed that voluntary disclosure is more accurate compared to analyst predictions (Basi et al. 1976; Ruland 1978; Waymire 1986; Hassell and Jennings 1986; Jung 1997). Basi et al. (1976) assumed that earnings posted by managers are more accurate because none has better access to private information of a company except managers. Their empirical analysis verified the assumptions that accuracy of voluntary forecast is in fact higher than that of analyst forecasts. Another comparison was made by Ruland (1978) who found the difference between voluntary disclosure and analyst forecasts issued before and after such disclosure. It indicated that voluntary disclosure is more accurate than analyst forecasts, thanks to managers' exclusive ownership of information relevant to their company, for example, latest market trends, past accounting records, business strategies and future plans.

Meanwhile, Jung (1997) compared the accuracy of voluntary earnings forecast, analyst forecast and forecast based on a random walk model. He used voluntary disclosure posted on daily newspapers from 1993 to 1996 in his analysis, in which they are proven more accurate than forecasts generated by a random walk model. Interestingly, accuracy between voluntary and analyst forecast showed no meaningful difference, but both tend to overestimate future earnings. Sohn (1997) further explained voluntary forecast issued via investor relations (IR) material is statistically more accurate than analyst forecast, and found analysts do modify their forecast once IR information becomes available. Kwon et al. (2009) suggested that accuracy of disclosure increases when it comes to predicting gross profit, and also provided that shorter forecast horizon and pessimistic assessment results in high accuracy. Generally, voluntary disclosure becomes an accurate source of information in terms of profit and short-term prediction (not revenue and long-term), and conservativism in reporting contributed to increased accuracy.

Studies have followed investigating which factors influence forecast precision. Assuming forecast horizon and earnings volatility as proxies for uncertainties in forecast, Baginski and Hassell (1997) examined how forecast precision is affected by the amount of information available, both in terms of private (as proxied by number of analysts) and public (as proxied by firm size) information. They argued that four major factors make voluntary disclosure less precise; longer forecast horizon, higher earnings volatility in the capital market, less number of analysts and larger firm size.

\subsection{Hypotheses Development}

Voluntary forecast can assist in decision-making of investors in a way that it signals managers' ability and delivers timely and relevant information (Trueman 1986; Beyer et al. 2010). It also can be useful means for managers to build a strong reputation and be assessed as capable resources by the investors (Verrecchia 2001).

A number of studies examined economic incentives behind voluntary disclosure decisions and suggested several forces including hypotheses regarding capital markets transactions, stock compensation, corporate control contest, litigation cost and management talent signaling (Healy and Palepu 2001; Beyer et al. 2010). Among these hypotheses, there has been no empirical research conducted on management talent signaling, which is defined as managers' incentive to make voluntary earnings forecasts to signal their ability (Trueman 1986). Most studies focus on explicit incentives such as stock option grants or equity participation, while no evidence exists on the subject of implicit incentives including career concerns or reputational concerns. Jensen and Meckling (1976) argued that monetary incentives and monitoring are effective solutions to agency problems, i.e., conflict of interests between managers and investors, and many others extended their studies with supporting evidence from empirical analysis (Aboody and Kasznik 2000; Nagar et al. 2003). Some studies hypothesized that career concerns or reputational concerns exert influence on managers' behavior (Fama 1980; Gibbons and Murphy 1992). Fama (1980), in particular, provided that career concerns may impact management performance, explaining a close relationship between managers and the labor market in which the market constantly assess managers' ability and adjust their credibility depending on their performance results and managers pay close attention to the market's response. As poor management performance often leads to a cut in compensation and early dismissal, managers are driven to avoid such punitive measures by working in investors' interests. Hermalin and Weisbach (2012) investigated whether voluntary disclosure is another motivation to resolve agency problems. Despite the general belief that voluntary disclosure alleviates agency problems, they refuted with theoretical analysis that disclosure decisions can worse agency problems and increase 
expenses, i.e., manager compensation expense. When faced with pressing demands to issue forecast disclosure, companies often experience increased compensation costs and high manager turnover. In their studies, they suggested it would be of potential interest to explore whether managers have shorter tenure at a company where disclosure is issued frequently and the quality of forecast is high. This indicates interesting relationship between voluntary disclosure and the length of tenure.

In this regard, it is a meaningful approach to examine how implicit incentives given to managers influence their disclosure decisions. In this paper, career concerns and reputational concerns are employed as key implicit incentives and as was in other literature, tenure is viewed as a proxy for both concerns (Gibbons and Murphy 1992).

Provided that voluntary disclosure acts as a signal of managers' ability to forecast earnings (Trueman 1986) and a mechanism to establish and strengthen a reputation among investors (Verrechia 2001), short-tenured managers are highly motivated to tap into voluntary disclosure so as to maximize their chances of securing monetary and nonmonetary compensation such as promotion. Managers with short experience are generally faced with high career concerns as the market has little knowledge about their ability (Gibbons and Murphy 1992). Under this circumstance, signaling their ability through voluntarily engaging in earnings disclosure is essential to deal with market's uncertainties and thereby the likelihood of their dismissal. In other words, voluntary disclosure will help the managers move their reputation in a positive direction. In contrast, long-tenured managers are less motivated to signal their ability in the market since their reputation is already built and set. For example, those who have succeeded in extending their term would regard the market has already recognized their ability, and for them, generating tangible results could be far more effective to impress investors than disclosing earnings forecast. In conclusion, propensity for voluntary disclosure is closely related to how long managers have been in that position.

It is when managers are more attached to explicit incentives such as compensation contract rather than implicit incentives that retirement approaches in later years (Gibbons and Murphy 1992). Managers with long tenure are motivated to take full opportunity of increasing the value of their monetary compensation such as stock option portfolios (Cassell 2012). Obviously, some of long-tenured managers may have high implicit incentives in case they seek opportunities to serve at other companies after retirement (Brinkley et al. 1999). In fact, they may rather be highly incentivized to signal their ability in the labor market. Even if they are not interested in continuing their job, others may also have strong implicit incentives in the form of career concerns if a fear of retirement looms large. If this is true, voluntary forecast is not expected to be an exclusive tool for short-tenured managers. To understand how implicit incentives (i.e., career concerns) influence managers with both short and long tenure to disclose forecast, I conducted an empirical analysis to review relationship between tenure and the likelihood of voluntary forecast. Since it is uncertain whether voluntary disclosure is a preferred choice among short or long-tenured managers, my first hypothesis is stated in a null form.

H1: There is no relation between CEO tenure and the likelihood of issuing management earnings forecast.

With regards to voluntary disclosure, accuracy of such disclosure may be influenced by career concerns. If forecast disclosure is to help managers dissuade uncertainties about their ability, increase corporate value and lower cost of capital by delivering managerial information out in the market, the disclosed information should be timely and reliable to investors. When too much discrepancy exists between forecast and actual numbers, the forecast loses its reliability, leading to decrease in stock prices or damage to management reputation. For this reason, managers would make efforts to reduce forecast errors in order to prevent such opportunity costs (Jaggi and Sannella 1995; Kasznik 1999). Only reliable and credible forecast would properly function to signal managers' ability in the market and help deal with career concerns. If investors find forecast errors unacceptable, they would not likely to trust managers' ability and further consider the company as an inadequate investment target. As such, if short-tenured managers have implicit incentives to signal their ability and impress the market in a positive way, their voluntary forecast would likely be accurate. On the other hand, disclosure information derived from unreliable future prediction or motivated by managers' personal interests would be inaccurate and thus less meaningful. Cassell (2012) pointed out in his analysis that the top management tend to release a 'good news' forecast using optimistic language in the immediate year before their retirement compared to any given year. Naming such phenomenon as a 'horizon problem,' he explained that 
soon-to-be-retired managers are motivated to issue inaccurate forecast, expecting an increase in their stock option value or severance payment.

Meanwhile, long-tenured managers wishing to serve at other companies after retirement would need to signal their ability like any other managers do, and for them, accurate forecast disclosure will be highly in order. In addition, they would be less motivated to act for their own interests to keep their long-secured reputation intact (Diamond 1989). Inaccurate forecast would result in negative assessment of manager's ability, which could eventually lead to a replacement or dismissal (Lee et al. 2012), it is expected that managers would avoid any risk of damaging their reputation. As seen above, since it is also uncertain whether accuracy of forecast disclosure depends on the period of tenure, I used the following null hypothesis.

H2: There is no relation between CEO tenure and the accuracy of management earnings forecasts.

\section{RESEARCH DESIGN}

\subsection{Methodology and Variable Definitions}

\subsubsection{Definition of CEO}

Chief Executive Officers (CEOs) include various titles of corporate management, such as chairman, president, representative director, directors and etc. In this paper, CEOs are defined as top-ranking personnel among those who appear as presidents on executive profiles and the list of shareholders in TS2000. (Lee et al. 2007; Kwak and Choi 2011). In case there are more than two top-ranking personnel with the same president title, the one with higher shareholding is defined as a CEO (O et al. 2010).

\subsubsection{Model for Disclosure of Management Earnings Forecast}

The first objective of this paper is to explore how implicit incentives influence managers' decision-making on voluntary forecast disclosure. To this end, based on empirical models used in previous research, I added another variable of managers' tenure (as a proxy for career concerns) to the model and examined if such variable would produce statistically meaningful results. To test H1, I used the following equation as Model 1:

\section{Model 1}

MFD (MFD_S $)=\mathrm{a} 0+\mathrm{a} 1$ TENURE $+\mathrm{a} 2 \mathrm{SIZE}+\mathrm{a} 3 \mathrm{BTM}+\mathrm{a} 4 \mathrm{BETA}+\mathrm{a} 5 \mathrm{VOL}+\mathrm{a}$ ROE $+\mathrm{a}$ 7LEV $+\mathrm{a} 8 \mathrm{FOREIGN}+$ a9LNAGE + a10OPTION + a11OWN + Year Dummy + Industry Dummy +e

Where

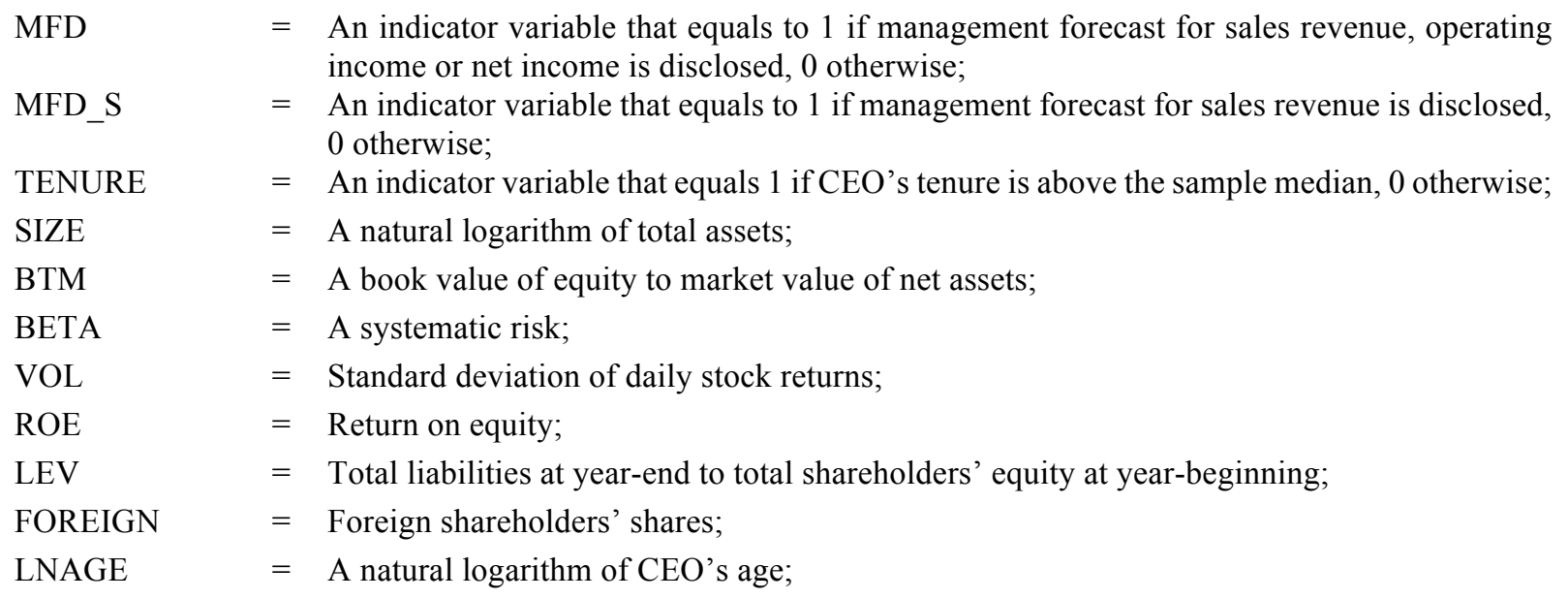




$\begin{array}{ll}\text { OPTION } & =\text { An indicator variable that equals } 1 \text { if stock option is granted to CEO, } 0 \text { otherwise; } \\ \text { OWN } & =\text { Percentage of CEO's ownership in the current year; } \\ \text { Year Dummy } & =\text { Dummy variables for year; } \\ \text { Industry Dummy } & =\text { Dummy variables for industry; } \\ \mathrm{e} & =\text { Residuals }\end{array}$

In the above Model that tests the influence of career concerns on disclosure of management earnings forecast, I alternately used MFD and MFD_S, both of which are dummy variables for management forecast disclosure. MFD is coded 1 if managers disclose any information on sales revenue, operating income or net income, and if no such information is disclosed, MFD is 0. MFD_S is coded 1 if managers disclose any sales revenue information, and if no such information is disclosed, it is coded 0 . As I used data on sales revenue to test the accuracy of earnings forecast that under Hypothesis 2, MFD_S is used alternately with MFD in order to compare the results.

Career concerns are the interest variable in [Model 1], in which TENURE is used as a proxy variable as previous research did so (Gibbons and Murphy 1992)3. TENURE represents the period of years serving as CEOs, and it is coded 1 if the period is above the sample median and 0 if below the median4. Market perceptions of manager's ability tend to affect their future career and the level of compensation. In this respect, it is likely that short-tenured CEOs have bigger career concerns and are more interested in knowing how they are evaluated in the labor market. Thus, they would be more motivated to signal their ability through voluntary earnings forecast and ensure fair evaluation by market participants. In this logic, I expect a1 would have a negative value.

Based on previous research, I included corporate size (SIZE), book-to-market ratio (BTM), systematic risk (BETA), debt to equity ratio (LEV), deviation of daily stock returns (VOL), return on equity (ROE), foreign ownership ratio (FOREIGN), CEO's age (LNAGE), availability of stock options (OPTION) and percentage of CEO's ownership $(\mathrm{OWN})$ as factors determining disclosure of forecast. Corporate size is a factor known to have a positive correlation with managers' likelihood for voluntary disclosure (Kasznik and Lev 1995; Lang and Lundholm 1996; Baginski et al. 2004). Book-to-market ratio (BTM) is a factor for growth opportunities and proprietary costs for disclosure (Bamber and Cheon 1998). It was found higher growth means wide fluctuation of future earnings and as such, growth opportunities affect disclosure of voluntary forecast (Cheon 2003). Return on equity (ROE) is profitability indexes that affect forecast disclosure, since firms with low ROE tend to make less forecast disclosure (Miller 2002) and managers have different incentives for disclosure depending on their firms' profit results (Burgstahler and Dichev 1997). Systematic risk (BETA) is used as a controlled variable, based on the previous finding that BETA is negatively related to managers' disclosure decisions (Ajinkya et al. 2005). Debt to equity ratio (LEV), an indicator of financial soundness, has mixed findings; Rajan (1992) explained that managers are less likely to disclose financial information if the debt to equity ratio is high, since a high debt ratio prompts lender institutions to increase control. On the contrary, Smith and Warner (1979) found that companies with a high debt to equity ratio disclose more information to reduce agency problems. Thus, the debt to equity ratio is included into the equation to control for its effects. Deviation of stock returns (VOL) is considered for managers expect that forecast disclosure would not result in volatile movements in stock prices (Baginski et al. 2004; Lang and Lundholm 1996). Foreign ownership ratio (FOREIGN) is included to control for its effects of motivating managers to disclose more reliable forecast information (Cheon 2003). CEO's age (LNAGE) is included to control for the correlated omitted variable problem, i.e., potential correlation between CEO's tenure and age. CEOs' stock option (OPTION) is to control for the statistically meaningful correlation between stockbased compensation and voluntary forecast disclosure (Nagar et al. 2003). And lastly, percentage of CEO's ownership

\footnotetext{
${ }^{3}$ Gibbons and Murphy (1992) first provided tenure as a proxy for career concerns, and many other subsequent researches have followed suit (Amihud and Lev 1981; May 1995; Bloom and Milkovich 1998; Chevalier and Ellison 1999; Chakraborty et al. 2007; John et al. 2008; Chen and Zheng 2012). In the meantime, it is possible that CEO's age could be another proxy for career concerns (although irrespective of age, short-tenured CEOs are more likely to build a strong reputation and signal their managerial capability). I conducted an empirical analysis (which is not presented in this paper) to study the relationship between CEO's age and disclosure of management forecast, using the age factor as an independent proxy variable. I obtained the same qualitative results for $\mathrm{H} 1$.

${ }^{4}$ Based on the findings from Gibbons and Murphy (1992), I used the sample median for tenure data. I also used other variables (which are not presented in this paper) such as tenure level, deciles ranking of CEO tenure and a dummy variable that equals one if the CEO is in his first two years as $\mathrm{CEO}$, and the qualitative results from these regressions are similar to those presented in the tables. 
in the current year (OWN) is considered as a key driver for forecast disclosure and alleviation of agency problems (Gelb 2000; Noe 1999; Lee and Sohn 2005). Year and industry dummy variables are added to the equation to control for any year and industry-specific effects.

\subsubsection{Model for Accuracy of Management Earnings Forecast}

The second objective of this paper is to understand relationship between CEO tenure and the accuracy of management earnings forecast. To this end, I measured the accuracy of forecast information using the following formula:

Accuracy of Management Forecast on Sales Revenue (MFA_S)

$$
=\frac{\mid \text { Sales Forecast }- \text { Actual Sales } \mid}{\text { Market Value of Net Assets }}
$$

As sales revenue is the most frequently disclosed financial information, I used sales data for my analysis of management forecast accuracy. Based on the above formula, the more accurate management forecast is, the smaller MFA_S variable becomes; so the less accurate management forecast is, the bigger the variable becomes. To test Hypothesis 2, I used the following equation as Model 2:

\section{Model 2}

MFA_S $=\mathrm{a} 0+\mathrm{a}$ TTENURE $+\mathrm{a}$ 2SIZE $+\mathrm{a} 3 \mathrm{BTM}+\mathrm{a}$ 4BETA $+\mathrm{a} 5 \mathrm{VOL}+\mathrm{a}$ ROE $+\mathrm{a}$ 7LEV $+\mathrm{a}$ 8FOREIGN $+\mathrm{a}$ 9LNAGE + a10LNHOR + a11OPTION + a12OWN + Year Dummy + Industry Dummy + e

Where

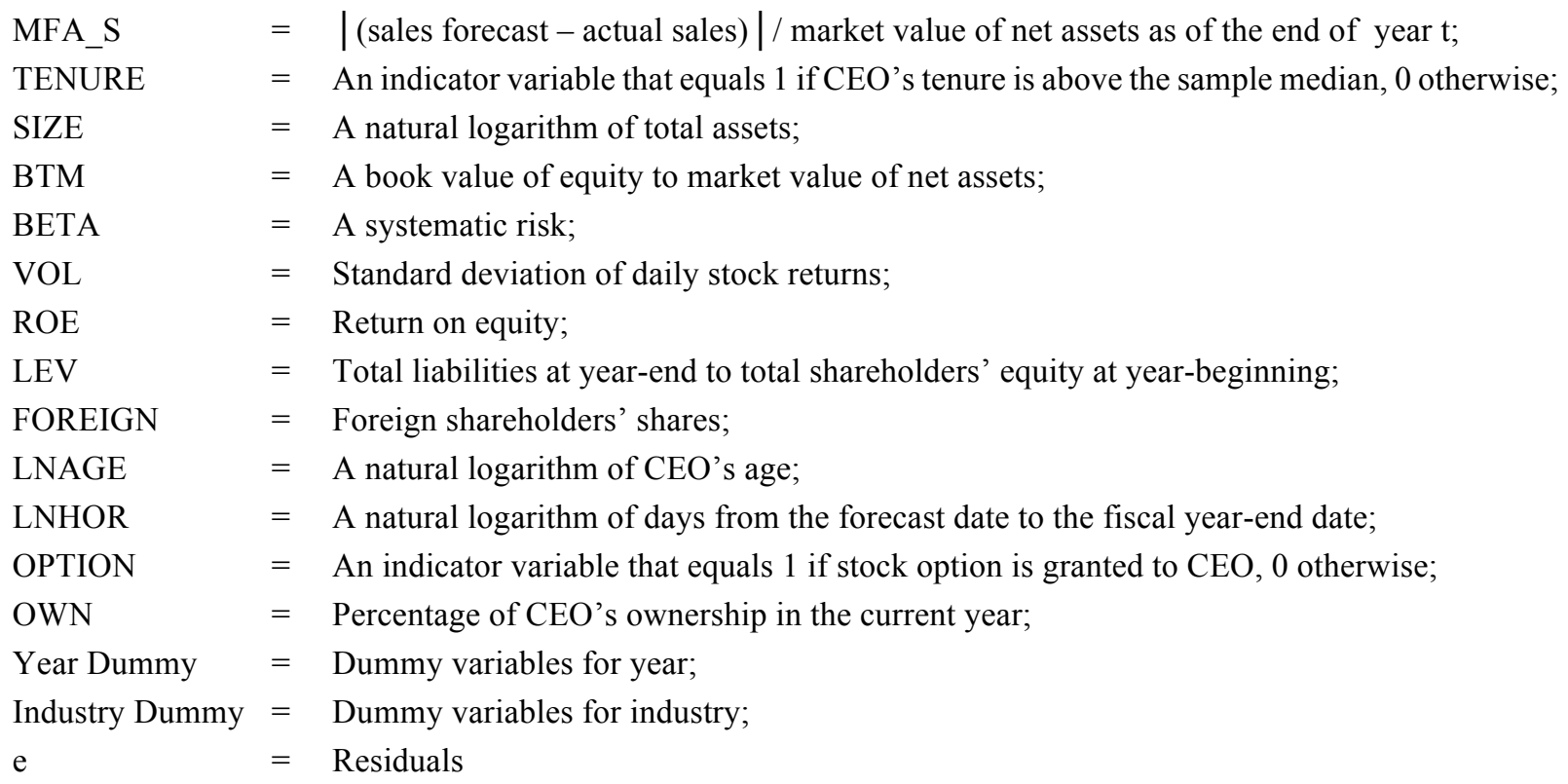

Career concerns are also the interest variable in [Model 2], in which TENURE is used as a proxy. The definition of TENURE is same as the definition introduced in Model 1 above. It is likely that short-tenured CEOs have bigger career concerns and therefore are highly motivated to signal their ability through voluntary earnings forecast. As such, I expect a1 would have a positive value.

Based on previous research, I included corporate size (SIZE), book-to-market ratio (BTM), systematic risk (BETA), deviation of daily stock returns (VOL), return on equity (ROE), debt to equity ratio (LEV), foreign ownership ratio 
(FOREIGN), CEO's age (LNAGE), prediction time horizon (LNHOR), availability of stock options (OPTION) and percentage of CEO's ownership (OWN) as factors determining accuracy of forecast. Corporate size (SIZE) is a factor known to motivate managers to disclose more reliable management forecast, as larger companies naturally entail more stakeholders. As noted by Botosan (1997), a positive correlation was found between corporate size and the quality of forecast information. In my analysis, I measured corporate size by taking natural logarithm of total assets. Book-tomarket ratio (BTM) is an index for growth potential in future earnings (Penman 1996). For rapid-growing companies, estimated future earnings are more relevant information than current earnings. As such, management earnings forecast becomes so important that managers are encouraged to disclose forecast as accurate as possible. Return on equity (ROE) and debt to equity ratio (LEV) are used as variables to control for profitability and financial distress. If companies are not profitable enough or financially distressed, managers may be inclined to adjust earnings upward and move investors in a positive direction (Frost 1997; Rogers and Stocken 2005; Rogers and Buskirk 2006). Deviation of stock returns (VOL) represents volatility of the business operation, and the more volatile the business is, the more difficult it is to predict future earnings and therefore earnings forecast becomes less accurate. Systematic risk (BETA) is used to control for the effects of specific risks inherent in companies. Prediction time horizon (LNHOR) is measured as logarithm of days from the forecast date to the fiscal year-end date in which the forecast is made. It is expected that a short horizon would have less uncertainties, resulting in more accurate forecast disclosure. In fact, Hassell and Jennings (1986) showed that accuracy in earnings forecast is lowered considerably when a prediction is made in a longer span of time. Foreign ownership ratio (FOREIGN) is included to control for its effects of motivating managers to disclose more accurate forecast information (Cheon 2003). CEO's age (LNAGE) is included to control for the correlated omitted variable problem, i.e., potential correlation between CEO's tenure and age. CEOs' stock option (OPTION) is to control for the statistically meaningful correlation between stock-based compensation and voluntary forecast disclosure (Nagar et al. 2003). Percentage of CEO's ownership in the current year (OWN) is included to reflect the fact that managers holding less shares tend to report better quality earnings, resolving agency issues (Gelb 2000). Year and industry dummies are added to the equation to control for cross-sectional dependence common to the samples selected.

\subsection{Sampling}

The samples used in my analysis consist of publicly listed companies that issued voluntary management earnings forecast under fair disclosure principle, during the sample period from November 2002 to December 2011. Management earnings forecast is manually retrieved from such companies' business reports on the electronic disclosure system of the Financial Supervisory Service5. CEO profiles and tenure information are also manually retrieved from executive profiles and list of shareholders on TS2000. Key variables are derived from financial information and standard industrial classification codes available in KISVALUE Library. In selecting the samples, the following limitations are applied:

1. Fiscal year-end falls on December 31

2. Banking and financial institutions are excluded

3. Financial information is available in KISVALUE

4. Disclosure is issued in the same year for which the forecast is made

5. In case forecast is made multiple times within a year, only the one closet to year-end is used

Under (1), companies whose fiscal year does not end in December 31 are excluded in order to control for the effects of different fiscal year-end. Under (2), banking and financial institutions are excluded since they prepare financial statements in conformity with different accounting principles and therefore the data requires interpretation different from that of non-banking companies. And (4) enables comparing forecast and actual earnings more effective in measuring data accuracy. Meanwhile, I removed the top and bottom $1 \%$ of forecast from the sample by doing a winsorization at the $1 \%$ level, to minimize the effect of extreme outliers. The final samples consist of 5,684 firm-year observations, out of which 1,066 firm-year observations provide management forecast earnings $(1,052$ firm-year observations provide sales revenue forecast).

\footnotetext{
${ }^{5}$ On the electronic disclosure system, management earnings forecast include point forecast, range forecast, forecast in dollar terms, etc. In my research, only point forecast is used to make comparison with actual earnings easier.
}

Copyright by author(s); $\underline{\mathrm{CC}-\mathrm{BY}}$ 


\section{RESULTS}

\subsection{Descriptive Statistics and Correlations}

Table 1 reports descriptive statistics for the main variables used in my analysis. Panel A provides that MFD, the dummy variable for management forecast disclosure, is 0.188 , i.e., $18.8 \%$ of the total sample companies disclose management earnings forecast. The average CEO tenure is 4.996 years. The average and median value of OPTION is 0.060 and 0.000 , respectively, meaning that more than $50 \%$ of the sample companies do not provide stock options to CEOs.

Panel B and Panel C each presents descriptive statistics of non-disclosing and disclosing companies. The average and median value of MFA_S, the variable for accuracy of management forecast, is 0.127 and 0.052 , respectively. This is consistent with the view by Kwon et al. (2009) that management earnings forecast is inherently positive. The CEO tenure is 4.432 years for disclosing companies and 5.127 years for non-disclosing companies, meaning that shorttenured CEOs are more likely to disclose forecast information. The average and median value of SIZE for nondisclosing companies are 26.304 and 20.063, respectively; reflecting that natural logarithm of total assets has a high degree of regularity. This is same for disclosing companies as well, although their average and median value SIZE are both higher than those of non-disclosing samples. Moving on to the financial variables, the average value of BTM for disclosing companies is 1.806 , comparatively higher than 1.165 for non-disclosing companies. The average value of systematic risk BETA is 0.934 for disclosing companies and 0.735 for non-disclosing ones. The average value of VOL does not show significant difference between disclosing and non-disclosing companies. The average value of ROE is 0.102 for disclosing companies and 0.041 for non-disclosing ones, indicating that profitable companies are more likely to make forecast disclosure. In terms of LEV, the average values for disclosing and non-disclosing companies are 0.446 and 0.472 , respectively, similar to the results shown in the prior research (Cheon and Chon 2009). The average value of FOREIGN is 0.174 for disclosing companies and 0.089 for non-disclosing ones, suggesting that foreign ownership motivates managers to disclose more earnings forecast. The average of CEO_AGE before natural logarithm is 54.730 for the total samples. The average of HOR before natural logarithm is 262 days, meaning that most management forecast disclosure takes place during the first three months of a year. The average value of OPTION for disclosing companies is 0.114 , higher than 0.048 for non-disclosing companies.

Table 1. Descriptive Statistics

This table provides descriptive statistics for the variables for model (1) and (2) in the text. MFD is an indicator variable that equals to 1 if
management forecast for sales revenue, operating income or net income is disclosed, 0 otherwise. MFA_S is measured by | (sales forecast -
actual sales) | /market value of net assets as of the end of year t. CEO_TENURE is the number of years since a manager is appointed as a CEO.
SIZE is measured by natural logarithm of total assets. BTM is book to market ratio which is measured by book value of equity to market value
of net assets. BETA is systematic risks. VOL is the standard deviation of daily stock returns for the one year period before management forecasts.
ROE is return on equity. LEV is measured by total liabilities to total shareholders' equity. FOREIGN is foreign shareholders' shares. LNAGE
is natural logarithm of CEO's age. OPTION is an indicator variable that equals 1 if stock option is granted to CEO, 0 otherwise. OWN is
percentage of CEO's ownership in the current year.

Panel A: Descriptive statistics of total sample (Number of observations: 5,684)

\begin{tabular}{l|r|r|r|r|r}
\hline \multicolumn{1}{c}{ Variables } & Mean & $\mathbf{5 \%}$ & Median & $\mathbf{9 5 \%}$ & S.D. \\
\hline MFD & 0.188 & 0.000 & 0.000 & 1.000 & 0.390 \\
\hline CEO_TENURE & 4.996 & 1.000 & 4.000 & 12.000 & 3.450 \\
\hline SIZE & 26.529 & 24.447 & 26.213 & 29.666 & 1.550 \\
\hline BTM & 1.686 & 0.323 & 1.329 & 4.346 & 1.291 \\
\hline BETA & 0.773 & 0.191 & 0.757 & 1.427 & 0.372 \\
\hline VOL & 0.526 & 0.275 & 0.494 & 0.893 & 0.189 \\
\hline ROE & 0.053 & -0.260 & 0.075 & 0.267 & 0.190 \\
\hline LEV & 0.446 & 0.136 & 0.453 & 0.755 & 0.191 \\
\hline FOREIGN & 0.105 & 0.000 & 0.033 & 0.471 & 0.154 \\
\hline LNAGE & 3.961 & 3.584 & 4.007 & 4.277 & 0.220 \\
\hline CEO_AGE & 54.730 & 42.000 & 57.000 & 73.000 & 79.020 \\
\hline OPTION & 0.060 & 0.000 & 0.000 & 1.000 & 0.237 \\
\hline OWN & 0.069 & 0.000 & 0.001 & 0.310 & 0.113 \\
\hline
\end{tabular}

(Table 1, Panel B continued on next page) 
(Table 1 continued)

Panel B: Descriptive statistics of non-disclosure sample (Number of observations: 4,618)

\begin{tabular}{l|r|r|r|r|r}
\hline \multicolumn{1}{c}{ Variables } & Mean & $\mathbf{5 \%}$ & Median & $\mathbf{9 5 \%}$ & S.D. \\
\hline CEO_TENURE & 5.127 & 1.000 & 4.000 & 12.000 & 3.521 \\
\hline SIZE & 26.304 & 24.375 & 26.063 & 29.155 & 1.415 \\
\hline BTM & 1.806 & 0.355 & 1.462 & 4.564 & 1.331 \\
\hline BETA & 0.735 & 0.172 & 0.715 & 1.347 & 0.360 \\
\hline VOL & 0.528 & 0.270 & 0.497 & 0.907 & 0.194 \\
\hline ROE & 0.041 & -0.300 & 0.066 & 0.259 & 0.196 \\
\hline LEV & 0.440 & 0.130 & 0.446 & 0.758 & 0.192 \\
\hline FOREIGN & 0.089 & 0.000 & 0.022 & 0.418 & 0.143 \\
\hline LNAGE & 3.962 & 3.584 & 4.007 & 4.290 & 0.223 \\
\hline CEO_AGE & 55.035 & 42.000 & 57.000 & 74.000 & 78.405 \\
\hline OPTION & 0.048 & 0.000 & 0.000 & 1.000 & 0.213 \\
\hline OWN & 0.070 & 0.000 & 0.001 & 0.310 & 0.114 \\
\hline
\end{tabular}

\begin{tabular}{|c|c|c|c|c|c|}
\hline \multicolumn{6}{|c|}{ Panel C: Descriptive statistics of disclosure sample (Number of observations: 1,052) } \\
\hline Variables & Mean & Min. & Median & Max & S.D. \\
\hline MFA_S & 0.127 & 0.000 & 0.052 & 1.562 & 0.215 \\
\hline CEO_TENURE & 4.432 & 1.000 & 4.000 & 14.000 & 3.061 \\
\hline SIZE & 27.504 & 23.766 & 27.330 & 30.906 & 1.722 \\
\hline BTM & 1.165 & 0.157 & 0.898 & 6.933 & 0.939 \\
\hline BETA & 0.934 & -0.002 & 0.926 & 1.687 & 0.379 \\
\hline VOL & 0.513 & 0.204 & 0.481 & 1.196 & 0.166 \\
\hline ROE & 0.102 & -0.970 & 0.110 & 0.470 & 0.154 \\
\hline LEV & 0.472 & 0.066 & 0.496 & 0.886 & 0.185 \\
\hline FOREIGN & 0.174 & 0.000 & 0.108 & 0.792 & 0.180 \\
\hline LNAGE & 3.956 & 3.584 & 4.007 & 4.419 & 0.205 \\
\hline CEO_AGE & 53.431 & 30.000 & 57.000 & 85.000 & 81.611 \\
\hline LNHŌ & 5.369 & 0.000 & 5.740 & 5.886 & 0.836 \\
\hline HOR & 262.511 & 0.000 & 311.000 & 364.000 & 106.964 \\
\hline OPTION & 0.114 & 0.000 & 0.000 & 1.000 & 0.317 \\
\hline OWN & 0.065 & 0.000 & 0.001 & 1.843 & 0.127 \\
\hline
\end{tabular}

Table 2 provides the Pearson's correlation between the main variables used in my empirical analysis. According to my calculation of correlative value between dependent variables and the interest variable using Model 1, I found that the correlation between MFD (the dummy variable for management forecast disclosure) and TENURE (the dummy variable for tenure) is statistically significant at $1 \%$ the level. This indicates my first hypothesis is valid that there is no relation between tenure and the likelihood of issuing management earnings forecast, i.e., short-tenured CEOs have a higher tendency to disclose voluntary earnings forecast. In terms of forecast accuracy, a statistically meaningful positive correlation is observed between MFA_S (accuracy of forecast) and TENURE, indicating that short-tenured CEOs pay more attention on accuracy of earnings forecast. This is also in line with my second hypothesis. That being said, these results are limited since I did not control other variables. The final conclusion must be reached on the basis of the regression results.

Additionally, I explored correlative value between dependent variables and main control variables. As the prior research (Kwon et al. 2009) suggests, managers are more likely to disclose earnings forecast when SIZE is larger and ROE is higher. Also, management earnings forecast is more prevalent if BTM and VOL is lower and FOREIGN is higher. Availability of OPTION and low OWN turn out to motivate managers to voluntarily disclose forecast. Meanwhile, accuracy of earnings forecast improves when VOL is lower and LNHOR is shorter.

In order to deal with meaningful associations found between the explanatory variables, I computed the variance inflation factor (VIF) for the Models. With VIFs ranging from 1.023 to 3.209, it turned out that multicollinearity is not a serious problem in my regression analysis. 
Table 2. Correlations Between Key Variables

This table presents Pearson correlation between CEO's tenure, management forecasts and other key variables. Please refer to the note of Table 1 for the definition of the variables. Bold numbers denote the significance levels at 5 percent or less.

Panel A: Pearson correlation between CEO's tenure, disclosure of management forecasts and other key variables

\begin{tabular}{|c|c|c|c|c|c|c|}
\hline & MFD & TENURE & SIZE & BTM & BETA & VOL \\
\hline MFD & 1.000 & & & & & \\
\hline TENURE & -0.064 & 1.000 & & & & \\
\hline SIZE & 0.302 & -0.070 & 1.000 & & & \\
\hline BTM & -0.194 & 0.086 & -0.135 & 1.000 & & \\
\hline BETA & 0.208 & -0.031 & 0.357 & -0.251 & 1.000 & \\
\hline VOL & -0.031 & -0.111 & -0.244 & -0.099 & 0.316 & 1.000 \\
\hline ROE & 0.124 & 0.053 & 0.208 & -0.106 & 0.025 & -0.254 \\
\hline LEV & 0.066 & -0.114 & 0.168 & -0.046 & 0.199 & 0.271 \\
\hline FOREIGN & 0.214 & 0.007 & 0.486 & -0.274 & 0.106 & -0.243 \\
\hline LNAGE & -0.011 & 0.180 & 0.093 & 0.075 & -0.012 & -0.090 \\
\hline OPTION & 0.108 & -0.089 & 0.132 & -0.105 & 0.116 & $0.023^{*}$ \\
\hline OWN & $-0.027^{* *}$ & 0.292 & -0.159 & $0.023^{*}$ & -0.041 & -0.020 \\
\hline & ROE & LEV & FOREIGN & LNAGE & OPTION & OWN \\
\hline ROE & 1.000 & & & & & \\
\hline LEV & -0.240 & 1.000 & & & & \\
\hline FOREIGN & 0.225 & -0.141 & 1.000 & & & \\
\hline LNAGE & 0.073 & 0.016 & -0.009 & 1.000 & & \\
\hline OPTION & -0.008 & 0.056 & 0.096 & -0.036 & 1.000 & \\
\hline OWN & 0.041 & -0.191 & -0.080 & 0.183 & -0.149 & 1.000 \\
\hline
\end{tabular}

Panel B: Pearson correlation between CEO's tenure, accuracy of management forecasts and other key variables

\begin{tabular}{l|r|r|r|r|r|r}
\hline & MFA_S & TENURE & SIZE & BTM & BETA & VOL \\
\hline MFA_S & & & & & & \\
\hline TENURE & 0.071 & 1.000 & & & & \\
\hline SIZE & -0.110 & -0.070 & 1.000 & & & \\
\hline BTM & 0.001 & 0.086 & -0.135 & 1.000 & & \\
\hline BETA & 0.048 & -0.031 & 0.357 & -0.251 & 1.000 & 1.000 \\
\hline VOL & 0.149 & -0.111 & -0.244 & -0.099 & 0.316 & -0.254 \\
\hline ROE & -0.170 & 0.053 & 0.208 & -0.106 & 0.025 & 0.271 \\
\hline LEV & 0.002 & -0.114 & 0.168 & -0.046 & 0.199 & -0.243 \\
\hline FOREIGN & -0.045 & 0.007 & 0.486 & -0.274 & 0.106 & -0.090 \\
\hline LNAGE & -0.037 & 0.180 & 0.093 & 0.075 & -0.012 & -0.036 \\
\hline LNHOR & 0.146 & -0.058 & 0.309 & -0.200 & 0.209 & 0.116 \\
\hline OPTION & -0.022 & -0.089 & 0.132 & -0.105 & 0.023 & -0.020 \\
\hline OWN & 0.028 & 0.292 & -0.159 & 0.023 & -0.041 & \\
\hline
\end{tabular}

\begin{tabular}{|c|c|c|c|c|c|c|c|}
\hline & ROE & LEV & FOREIGN & LNAGE & LNHOR & OPTION & OWN \\
\hline ROE & 1.000 & & & & & & \\
\hline LEV & -0.240 & 1.000 & & & & & \\
\hline FOREIGN & 0.225 & -0.045 & 1.000 & & & & \\
\hline LNAGE & 0.073 & 0.016 & -0.009 & 1.000 & & & \\
\hline LNHOR & 0.119 & 0.064 & 0.219 & -0.009 & 1.000 & & \\
\hline OPTION & -0.008 & 0.056 & 0.096 & -0.036 & 0.108 & 1.000 & \\
\hline OWN & 0.041 & -0.191 & -0.080 & 0.183 & -0.028 & -0.149 & 1.000 \\
\hline
\end{tabular}




\subsection{Regression Analysis Results}

\subsubsection{Analysis Results for Model 1 (Disclosure of Management Earnings Forecast)}

With Hypothesis 1, I aimed to test if there is any relation between CEO tenure and the likelihood of earnings forecast disclosure. For that purpose, I designed Model 1 in which managers' tenure (a proxy for career concerns) is added as a dependent variable. The results of my logistics regression in Table 3 explain how CEOs' career concerns impact their behavior on disclosure of management earnings forecast.

The regression coefficient on MFD is -0.194 , showing that it is significantly negative at the $5 \%$ level. When the variable is replaced with MFD_S, the coefficient is also significantly negative. This indicates that short-tenured CEOs have bigger career concerns, resulting in increased incentives to signal their ability to the market where voluntary disclosure becomes an effective mechanism to accomplish their goals. In other words, CEOs concerned about their career are highly incentivized to provide investors with management earnings forecast.

In terms of relationship between dependent variables and main control variables, firstly, I found that SIZE is positively correlated with disclosure of earnings forecast at the $1 \%$ level, i.e., the larger a firm is, the more likely its stakeholders require forecast information and CEOs, accordingly, have to meet such requests for forecast disclosure. This is consistent with prior studies' findings by Lang and Lundholm (1993), Kaznik and Lev (1995) and Frankel et al. (1995). The coefficient on BTM and VOL are both significantly negative, i.e., CEOs working at financially distressed firms are less likely to disclose forecast. In the same sense, disclosure becomes more frequent if firms provide stock-based options to CEOs and the profitability is sound, proven by the positive regression coefficient on ROE and OPTION at 0.899 and 0.355 , respectively. The regression coefficient on LEV is positive, meaning that firms with higher debt-toequity ratio tend to disclose more forecast data in an attempt to preempt litigation risks (Lee and Sohn 2005). LNAGE is negatively correlated with disclosure of earnings forecast, as young managers are more inclined to release earnings forecast.

Table 3. Results of regression tests of the likelihood of issuing management earnings forecasts This table provides the results of logistics regression for Model (1). Please refer to the note of Table 1 for the definition of the variables except for the following. MFD_S is an indicator variable that equals to 1 if management forecast for sales revenue is disclosed, 0 otherwise. TENURE is an indicator variable if CEO's tenure is above the sample median. *, ** and *** denotes significance at $0.10,0.05,0.01$ levels, respectively, using a two-tailed test.

MFD (MFD_S) $=\mathrm{a} 0+\mathrm{a}$ TTENURE $+\mathrm{a}$ SSIZE $+\mathrm{a} 3 \mathrm{BTM}+\mathrm{a} 4 \mathrm{BETA}+\mathrm{a}$ 5VOL $+\mathrm{a} 6 \mathrm{ROE}+\mathrm{a}$ 7LEV $+\mathrm{a}$ 8FOREIGN $+\mathrm{a}$ LLNAGE $+\mathrm{a} 100$ PTION + a11OWN + Year Dummy + Industry Dummy +e

\begin{tabular}{|c|c|c|c|c|}
\hline \multirow{2}{*}{ Variable } & \multicolumn{2}{|c|}{ MFD } & \multicolumn{2}{|c|}{ MFD_S } \\
\hline & Coefficient & Wald Chi-Square & Coefficient & Wald Chi-Square \\
\hline INTERCEPT & $-13.964^{* * * *}$ & 76.75 & $-13.659^{* * *}$ & 73.24 \\
\hline TENURE & $-0.194^{* *}$ & 5.28 & $-0.195^{* *}$ & 5.15 \\
\hline SIZE & $0.428^{* * *}$ & 125.51 & $0.428^{* * *}$ & 124.14 \\
\hline BTM & $-0.482^{* * *}$ & 84.89 & $-0.492^{* * *}$ & 87.01 \\
\hline BETA & $0.357^{* *}$ & 5.90 & $0.328^{* *}$ & 4.96 \\
\hline VOL & $-0.601^{*}$ & 3.43 & $-0.617^{*}$ & 3.58 \\
\hline ROE & $0.890^{* * *}$ & 11.43 & $0.902^{* * *}$ & 11.63 \\
\hline LEV & $0.603^{* *}$ & 5.18 & $0.590^{* *}$ & 4.88 \\
\hline FOREIGN & 0.392 & 1.67 & 0.318 & 1.09 \\
\hline LNAGE & $-0.506^{* * *}$ & 6.73 & $-0.571^{* * *}$ & 8.36 \\
\hline OPTION & $0.405^{* * *}$ & 7.26 & $0.425^{* * *}$ & 7.93 \\
\hline OWN & $0.990^{* * *}$ & 11.48 & $1.298^{* * *}$ & 10.45 \\
\hline Year Dummy & \multicolumn{2}{|c|}{ Included } & \multicolumn{2}{|c|}{ Included } \\
\hline Industry Dummy & \multicolumn{2}{|c|}{ Included } & \multicolumn{2}{|c|}{ Included } \\
\hline Likelihood Ratio & \multicolumn{2}{|c|}{1307.6891} & \multicolumn{2}{|c|}{1284.883} \\
\hline R2 & \multicolumn{2}{|c|}{0.2055} & \multicolumn{2}{|c|}{0.2023} \\
\hline Number of Observations & \multicolumn{2}{|c|}{5,684} & \multicolumn{2}{|c|}{5,684} \\
\hline
\end{tabular}




\subsubsection{Analysis Results for Model 2 (Accuracy of Management Earnings Forecast)}

The purpose of Hypothesis 2 is to understand how CEO tenure affects the accuracy of management earnings forecast. Table 4 provides the results of regression analysis using Model 2, in which career concerns are included as the interest variable to test the accuracy of earning forecast.

The regression coefficient on MFA_S is 0.028 , showing that it is significantly positive at the 5\% level. Assuming that career concerns motivate CEOs to provide earnings forecast more frequent, those who are concerned and interested to signaling their managerial ability would naturally pay more attention to accuracy of the forecast.

The value of coefficient on VOL and ROE is 0.201 and -0.220 , respectively, i.e., earnings forecast released by financially stable and profitable firms are more accurate and precise. The coefficient on LNHOR is significantly positive at the $1 \%$ level, as the prior study by Baginski and Hassell (1997) suggested, i.e., the shorter management forecast more precise.

Table 4. Results of regression tests of the accuracy of management earnings forecasts

This table reports the regression results for model (2). Please refer to the note of Table 1 for the definition of the variables except for the following. TENURE is an indicator variable if CEO's tenure is above the sample median. ${ }^{*},{ }^{* *}$ and ${ }^{* * *}$ denotes significance at $0.10,0.05,0.01$ levels, respectively, using a two-tailed test.

\begin{tabular}{|c|c|c|}
\hline Variable & Coefficient & t-value \\
\hline INTERCEPT & 0.113 & 0.56 \\
\hline TENURE & $0.031^{* *}$ & 2.33 \\
\hline SIZE & -0.007 & -1.14 \\
\hline BTM & 0.002 & 0.22 \\
\hline BETA & -0.007 & -0.28 \\
\hline VOL & $0.201^{* * *}$ & 3.53 \\
\hline ROE & $-0.220^{* * *}$ & -4.75 \\
\hline LEV & -0.055 & -1.27 \\
\hline FOREIGN & 0.046 & 0.99 \\
\hline LNAGE & -0.015 & -0.45 \\
\hline LNHOR & $0.043^{* * *}$ & 4.96 \\
\hline OPTION & -0.017 & -0.79 \\
\hline OWN & -0.082 & -1.27 \\
\hline Year Dummy & \multicolumn{2}{|c|}{ Included } \\
\hline Industry Dummy & \multicolumn{2}{|c|}{ Included } \\
\hline F-value & \multicolumn{2}{|c|}{$4.250^{* * *}$} \\
\hline $\mathrm{R} 2$ & \multicolumn{2}{|c|}{0.1931} \\
\hline Number of Observations & \multicolumn{2}{|c|}{1,052} \\
\hline
\end{tabular}

\section{ADDITIONAL ANALYSIS}

\subsection{Self-Selection Bias}

This section explains how CEO tenure affect accuracy of management earnings forecast when self-selection bias is controlled. In general, CEOs make decisions first whether forecast would be made available, and then decide how precise and detailed such forecast should be. In this case, if same variables affect both former and latter decisions, self-selection bias arises. In order to address this issue, I used a two-stage regression model called the Heckman correction. Firstly, I obtained inverse Mill's ratio from the first-stage model that includes all the variables affecting CEO's forecast disclosure decisions. Next, the inverse Mill's ratio was added to the second-stage model as an explanatory variable. The below probit model is the first-stage model that predicts the possibility of forecast release. And based on several previous research, variables known to affect disclosure decisions are included as other explanatory variables as follows: 


\section{Model 3}

MFD $=\mathrm{a} 0+\mathrm{a}$ TTENURE $+\mathrm{a}$ 2SIZE $+\mathrm{a} 3 \mathrm{BTM}+\mathrm{a}$ 4BETA $+\mathrm{a}$ VVOL $+\mathrm{a}$ ROE $+\mathrm{a}$ 7LEV $+\mathrm{a}$ 8FOREIGN $+\mathrm{a}$ 9LNAGE

+ a10OPTION + a11OWN + Year Dummy + Industry Dummy + e

Where

MFD $=$ An indicator variable that equals to 1 if management forecast for sales revenue, operating income or net income is disclosed, 0 otherwise;

TENURE $=$ An indicator variable that equals 1 if CEO's tenure is above the sample median, 0 otherwise;

SIZE $\quad=$ A natural logarithm of total assets;

BTM = A book value of equity to market value of net assets;

BETA $\quad=$ A systematic risk;

VOL $=$ Standard deviation of daily stock returns;

ROE $\quad=$ Return on equity;

LEV $\quad=$ Total liabilities at year-end to total shareholders' equity at year-beginning;

FOREIGN $=$ Foreign shareholders' shares;

LNAGE $\quad=$ A natural logarithm of CEO's age;

OPTION $=$ An indicator variable that equals 1 if stock option is granted to CEO, 0 otherwise;

OWN $=$ Percentage of CEO's ownership in the current year;

Year Dummy $\quad=$ Dummy variables for year;

Industry Dummy = Dummy variables for industry;

e $\quad=$ Residuals

The inverse Mill's ratio derived from the above probit model is added to Model 2 as an independent variable, and I observed and compared the results. The bias-controlled results turn out to be fairly consistent with the main findings of my research, as shown in Table 5 below, i.e., earnings forecast released by short-tenured CEOs would likely to be more accurate and precise. 
Table 5. The Second-Stage Regression Results of the Association between CEO Tenure and Management Forecast Accuracy after Controlling for Firm's Self-Selection into Issuing a Management Forecast

Table 5 reports the second-stage regression results of the Association between CEO Tenure and Management Forecast Accuracy after Controlling for Firm's Self-Selection into Issuing a Management Forecast. Please refer to the note of Table 1 for the definition of the variables except for the following. TENURE is an indicator variable if CEO's tenure is above the sample median. IMR is the selectivity correction variable from the first-stage bivariate probit estimation. * $* *$ and $* * *$ denotes significance at $0.10,0.05,0.01$ levels, respectively, using a two-tailed test.

Panel A: Results of first-stage bivariate probit estimation

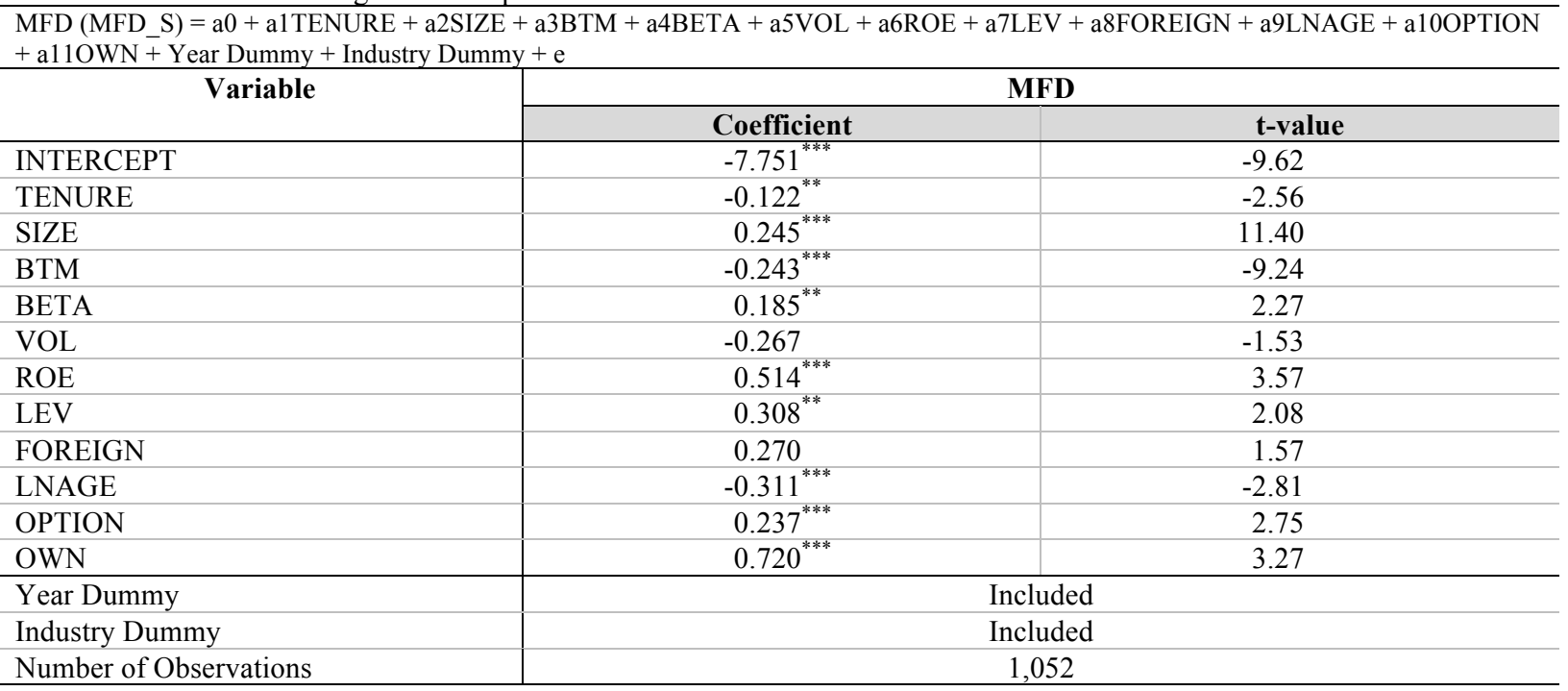

Panel B: The second-stage regression results for accuracy of management forecasts using Inverse Mill's Ratio(IMR)

MFA S = a0 + a1TENURE + a2SIZE + a3BTM + a4BETA + a5VOL + a6ROE + a7LEV + a8FOREIGN + a9LNAGE + a10LNHOR + a11OPTION + a12OWN + a13IMR + Year Dummy + Industry Dummy + e

\begin{tabular}{|c|c|c|}
\hline \multirow{2}{*}{ Variable } & \multicolumn{2}{|c|}{ MFA S } \\
\hline & Coefficient & t-value \\
\hline INTERCEPT & -0.126 & -0.490 \\
\hline TENURE & $0.235^{*}$ & 1.680 \\
\hline SIZE & -0.001 & -0.100 \\
\hline BTM & -0.013 & -1.170 \\
\hline BETA & 0.011 & 0.430 \\
\hline VOL & $0.188^{* * *}$ & 3.310 \\
\hline ROE & $-0.165^{* * *}$ & -3.360 \\
\hline LEV & -0.019 & -0.420 \\
\hline FOREIGN & 0.077 & 1.640 \\
\hline LNAGE & -0.023 & -0.670 \\
\hline LNHOR & $0.044^{* * *}$ & 5.170 \\
\hline OPTION & -0.001 & -0.410 \\
\hline OWN & -0.060 & -0.910 \\
\hline IMR & $0.071^{*}$ & 1.840 \\
\hline Year Dummy & \multicolumn{2}{|c|}{ Included } \\
\hline Industry Dummy & \multicolumn{2}{|c|}{ Included } \\
\hline Number of Observations & \multicolumn{2}{|c|}{1,052} \\
\hline
\end{tabular}

\subsection{Earnings Management}

Prior studies have provided that earnings management occurs when managers are concerned a certain difference would be found between forecast and actual earnings and such difference would render them unreliable, leading to a decrease of stock price, loss of reputation, litigation and other negative consequences. Kasznik (1999) argued that managers 
use positive discretionary accruals to make actual earnings reported close to forecast figures. Similarly, according to Cheon and Chon (2009), managers tend to manipulate actual earnings upward using positive discretionary accruals, when earnings would otherwise be below their forecast. Park and Nam (2010) also investigated whether managers manage actual earnings in order to meet the forecast; their conclusion was that managers manipulate reported earnings when firms have released overestimated forecast and such management using positive discretionary accruals takes place in the forecasting year.

Previous research including Pourciau (1993) suggested that accrual-based earnings management with the intent of obtaining private gains is found around CEO changes. Lee et al. (2007) discovered that negative association between CEO turnover and performance matched discretionary accruals which imply income-decreasing earnings management of a new CEO. Such negative relationship between management performance and discretionary accruals takes place in the year of CEO change, indicating a decrease in reported earnings via income-decreasing discretionary accruals. Kwak and Choi (2011) extended previous literature with a theory that different incentives are at work, depending on the type of CEO change. They showed that an external CEO succession (i.e., the former CEO retires and a new CEO is selected from outside the company) is associated with positive earnings management, while an internal one (i.e., a new CEO is promoted within the company) does not lead to earnings management behavior.

For the purpose of my analysis, I defined the accuracy of management earnings forecast as an absolute value of sales forecast minus actual sales. Considering that actual sales value might have been influenced under earnings management, the findings from my analysis, i.e., short-tenured CEOs provide more precise forecast, may not be free from the impact of earnings management. In this section, I examine how earnings management affect the accuracy of forecast value by including discretionary accruals variable to Model 2 as a controlled variable.

I conducted a cross-sectional analysis by year and by industry to obtain DA (discretionary accruals) variable, based on the Jones model (Dechow et al., 1995) as other previous research had done so (Subramanyam 1996; Choi and Baek 1998). The modified Jones model used for my analysis is as below:

$$
\mathrm{TAi}, \mathrm{t}=\mathrm{a} 0(1 / \mathrm{Ai}, \mathrm{t}-1)+\mathrm{a} 1[(\triangle \mathrm{REVi}, \mathrm{t}-\triangle \mathrm{RECi}, \mathrm{t}) / \mathrm{Ai}, \mathrm{t}-1]+\mathrm{a} 2(\mathrm{PPEi}, \mathrm{t} / \mathrm{Ai}, \mathrm{t}-1)+\varepsilon \mathrm{ei}, \mathrm{t}
$$

Where

TAi,t = total accruals in the event year ' $\mathrm{t}$ ' ( = net income $\mathrm{i}, \mathrm{t}-$ operating cash flow $\mathrm{i}, \mathrm{t})$ divided by beginning total assets;

Ai,t-1 = total assets in year ' $\mathrm{t}-1$ ';

$\triangle \mathrm{REVi}, \mathrm{t}=$ change in revenues from year ' $\mathrm{t}-1$ ' to year ' $\mathrm{t}$ ';

$\triangle \mathrm{RECi}, \mathrm{t}=$ change in account receivables from year ' $\mathrm{t}-1$ ' ' to year ' $\mathrm{t}$ ';

PPEi,t $=$ book value of property, plant and equipment in the event year ' $\mathrm{t}$ '

I applied the equation (1) cross-sectionally in each industry-year and derived the residual ( $\varepsilon$ ) representing the company-specific discretionary portion of the total accruals. Then I rerun Model 2 with the residual added as a controlled variable, only to find that discretional accruals have no impact on the outcome of my previous analysis. The results of this additional analysis, i.e., relationship between CEO tenure and accuracy of management forecast after controlling the effect of earnings management, are summarized in Table 6 below: 
Table 6. Results of Regression Tests for the Accuracy of Management Earnings Forecast After Controlling the Effect of Earnings Management

This table reports the regression results for the relationship between CEO tenure and accuracy of management forecast after controlling the effect of earnings management. Please refer to the note of Table 1 for the definition of the variables except for the following. TENURE is an indicator variable if CEO's tenure is above the sample median. *, ** and $* * *$ denotes significance at $0.10,0.05,0.01$ levels, respectively, using a two-tailed test.

MFA_S $=\mathrm{a} 0+\mathrm{a}$ TENURE $+\mathrm{a}$ 2SIZE $+\mathrm{a} 3 \mathrm{BTM}+\mathrm{a}$ 4BETA $+\mathrm{a} 5$ VOL $+\mathrm{a}$ 6ROE $+\mathrm{a}$ 7LEV + a8FOREIGN + a9LNAGE + a10LNHOR + a11OPTION + a12OWN + a13DA +Year Dummy + Industry Dummy + e

\begin{tabular}{|c|c|c|}
\hline \multirow{2}{*}{ Variable } & \multicolumn{2}{|c|}{ MFA S } \\
\hline & Coefficient & t-value \\
\hline INTERCEPT & 0.198 & 0.940 \\
\hline TENURE & $0.037^{* *}$ & 2.520 \\
\hline SIZE & $-0.013^{* *}$ & -2.010 \\
\hline BTM & 0.005 & 0.520 \\
\hline BETA & 0.021 & 1.180 \\
\hline VOL & $0.264^{* * *}$ & 4.810 \\
\hline ROE & $-0.175^{* * *}$ & -3.470 \\
\hline LEV & -0.070 & -1.510 \\
\hline FOREIGN & 0.069 & 1.330 \\
\hline LNAGE & -0.010 & -0.270 \\
\hline LNHOR & $0.043^{* * *}$ & 4.510 \\
\hline OPTION & 0.003 & 0.110 \\
\hline OWN & $-0.150^{* *}$ & -2.410 \\
\hline DA & 0.002 & 0.500 \\
\hline Year Dummy & \multicolumn{2}{|c|}{ Included } \\
\hline Industry Dummy & \multicolumn{2}{|c|}{ Included } \\
\hline Number of Observations & \multicolumn{2}{|c|}{891} \\
\hline F value & \multicolumn{2}{|c|}{$4.110^{* * *}$} \\
\hline $\mathrm{R} 2$ & \multicolumn{2}{|c|}{0.186} \\
\hline
\end{tabular}

\section{CONCLUSIONS}

In previous chapters, I explored how CEOs' career concerns influence their decision-making on forecast disclosure and accuracy of such forecast. Using CEOs' tenure as a proxy for career concerns, I conducted an empirical analysis examining whether tenure would act as implicit incentives to release forecast and determine the level of its accuracy. It is only natural to assume that career concerns are one of the key priorities for CEOs in Korea, given the average length of time spent at one company is 4.8 years and moreover, the average tenure at the 10 largest corporate groups is merely 2.97 years, falling short of a maximum term of 3 years provided by the Commercial Act. Prior studies proved that new or short-tenured CEOs have bigger career concerns than long-tenured CEOs (Gibbons and Murphy 1992) and they are highly motivated to demonstrate their ability to the labor market in order to ensure a good reputation and higher compensation. Based on management talent signaling hypothesis by Trueman (1986), which explained managers are motivated to signal their managerial ability through voluntary disclosure especially when the market is in doubt of their ability, I expected that management earnings forecast would be an attractive mechanism tool for managers to resolve career concerns.

Many research has been conducted on the issue of explicit incentives, such as stock options or management stock ownership, and their impact on agency problems (Aboody and Kaznik 2000; Nagar et al. 2003). It has also been found that implicit incentives such as career concerns or reputational concerns have significant impact on managers' behaviors (Fama 1980; Gibbons and Murphy 1992). In this regard, I hypothesized that both explicit and implicit incentives need to be considered as key factors for forecast disclosure. Furthermore, I presumed implicit initiatives would also affect accuracy of forecast as well. To empirically test my hypotheses, I used firm-year forecast observations from 5,684 companies over the period from 2002 to 2011. In terms of forecast accuracy, I observed absolute values of forecast less actual sales revenue divided by market value of net assets. 
I draw two conclusions from my empirical analysis. Firstly, new and short-tenured managers are more likely to disclose earnings forecast, driven by strong career concerns. It is because they are highly motivated to signal their ability to the market via voluntary earnings disclosure. On the other hand, long-tenured managers have less incentives to release forecast. Their business reputation has already been firmly established in the market and accordingly, there is little need to further signal their skills. Secondly, the level of accuracy and precision of forecast increases when managers are short-tenured. Only when forecast information is sufficiently reliable that the market provides a fair evaluation of those who issue the forecast. Unreliable forecast puts a huge dent to managers' credibility and it may further cause a decrease in stock prices or damage to management reputation. As such, short-tenured managers pay more attention on accuracy of disclosure information so as to maximize their chances of monetary and non-monetary compensation such as promotion or reappointment. Long-tenured managers are more attracted to explicit incentives such as compensation rather than implicit incentives (Gibbons and Murphy 1992), and they may be motivated to boost the value of their stock-based compensation at the expense of accuracy.

My empirical studies are strengthened by an additional analysis that addresses self-selection bias problems, using twostep regression procedure of Heckman (1979). Also, I added discretionary accruals variable to the regression model to examine how earnings management affect the accuracy of forecast value. According to such additional analyses, self-selection bias and discretional accruals have no impact on the outcome. Also, when using different TENURE variables, such as tenure level, deciles ranking of CEO tenure and a dummy variable that equals one if the CEO is in his first two years as CEO, the change of variable definition has no impact on the outcome.

This paper contributes to the existing literature by suggesting that implicit incentives such as career concerns motivate managers to disclose voluntary earrings forecast. There is ample prior research that indicates the relationship between CEOs' career concerns and their economic activities and behaviors (Fama 1980; Gibbons and Murphy 1992; Holmstrom 1999), but few conducted an empirical analysis to investigate career concerns from forecast disclosure perspectives. In addition, while prior studies are mostly limited to firm-specific and disclosure-specific characteristics when it comes to exploring to managers' incentives, this paper focused on a more fundamental driving force behind forecast disclosure, i.e., implicit incentives of those who are directly responsible for making disclosure decisions and determining forecast accuracy.

\section{AUTHOR BIOGRAPHIES}

Soo Yeon Park, Researcher, Institute for Business Research \& Education, Korea University, Business Main Building \#506, 145 Anam-ro, Seongbuk-gu, Seoul, Korea. Email: sooyeonpark@korea.ac.kr Telephone: +821090635728 (corresponding author)

Kwan Hee Yoo, Professor, Korea University, South Korea. E-mail: khyoo@korea.ac.kr

\section{REFERENCES}

Aboody, D. and R. Kasznik. 2000. "CEO Stock Option Awards and the Timing of Corporate Voluntary Disclosures", Journal of Accounting and Economics 29: 73-100.

Ajinkya, B., Bhojraj, S., and Sengupta, P. 2005. "The Association between Outside Directors, Institutional Investors and the Properties of Management Earnings Forecasts" Journal of Accounting Research 43(June): 343-376.

Akerlof, George. 1970. "The market for "lemons": Qualitative uncertainty and the market mechanism" Quarterly Journal of Economics 84: 488-500.

Ali, A. and Zhang, W. 2012. "CEO tenure and Earnings management" Working Paper. University of Texas at Dallas.

Baginski, S. P. and Hassell, J. M. 1997. "Determinants of management forecast precision” The Accounting Review 72 (April): 303-313.

Baginski, S. P., Hassell, J. M., and Kimbrough, M. D. 2004. "Why Do Managers Explain Their Earnings Forecasts?" Journal of Accounting Research 42(March): 1-29.

Baik, Bok, Farber, D. B., and Lee, Sam. 2011. "CEO Ability and Management Earnings Forecasts" Contemporary Accounting Research 28(Winter): 1645-1668.

Copyright by author(s); $\underline{\text { CC-BY }}$ 
Bamber, L. S. and Y. S. Cheon. 1998. "Discretionary Management Earnings Forecast Disclosures: Antecedents and Outcomes Associated with Forecast Venues and Forecast Specificity Choices" Journal of Accounting Research 36 (Autumn): 167-190.

Basi, B. A., J. C. Kenneth and D. T. Richard. 1976. "A Comparison of the Accuracy of Corporate and Security Analysts' Forecasts of Earnings" The Accounting Review 51(April): 244-254.

Beyer, A., D. A. Cohen, T. Z. Lys, and B. R. Walther. 2010. "The Financial Reporting Environment: Review of the Recent Literature" Journal of Accounting Economics 50: 296-343.

Beyer, A. and Dye, R. A. 2012. "Reputation management and the disclosure of earnings forecasts" Review of Accounting Studies 17: 877-912.

Botosan, C. A. 1997. "Disclosure level and the cost of equity capital" The Accounting Review 72(3): 323-350.

Brickley, J., J. Linck, and J. Coles. 1999. "What Happens to CEOs After they Retire? New Evidence on Career Concerns Horizon Problems, and CEO Incentives" Journal of Financial Economics 52(June): 341-377.

Burgstahler, D. and I.Dichev 1997 "Earnings management to avoid earnings decreases and losses" Journal of Accounting and Economics 24(1): 99-126.

Cassell, C., Huang, S. X., and Sanchez, J. M. 2012 "Forecasting without consequence? Evidence on the properties of retiring CEO's forecasts of future earnings" Working Paper. University of Arkansas.

Chen, D. and Zheng Y. 2012.”CEO tenure and risk-taking” Working Paper. University of Baltimore.

Cheon, Y. S. 2003. Foreign and Institutional Investors' Monitoring of Management earnings Forecast Disclosures. DAEHAN Journal of Business 38: 891-913.

Cheon, Y. S. and M. L. Chon. 2009. Earnings Management of Firms that Disclose Earnings Forecasts through Fair Disclosure. Journal of Taxation and Accounting 10(3): 329-356.

Chevalier, J. and Ellison, G.1999. "Career concerns of mutual fund managers" Quarterly Journal of Economics 114: $389-432$.

Coles, J.L., N.D. Daniel and L. Naveen. 2006. "Managerial incentives and risk-taking” Journal of Financial Economics 79: 431-468.

Cremers, M and Palia, D. 2011. "Tenure and CEO pay" Working Paper. Yale University.

Dechow. P. M., R. G. Sloan, and A. P. Sweeney 1995. "Detecting Earnings Management" The Accounting Review 70: 193-225.

Dewatripoint, M., Jewitt, I. and Tirole, J. 1999. "The economics of career concerns, Part I: Comparing information structures" Review of Economic Studies 66: 183-201.

Demers, E. and Wang, C. 2010. "The impact of CEO career concerns on accruals based and real earnings management" Working Paper. INSEAD.

Diamond, D. and Verrecchia, R. 1991. "Disclosure, liquidity, and the cost of capital" The Journal of Finance 66: 1325-1355.

Fama, Eugene. 1980. "Agency problems and the theory of the firm" Journal of Political Economics LXXXVIII: 288-307.

Frost, C. A. 1997. "Disclosure policy choices of UK firms receiving modified audit reports" Journal of Accounting and Economics 23: 163-188.

Gibbons, R., Murphy, K. J. 1992. "Optimal incentive contracts in the presence of career concerns: theory and evidence" Journal of Political Economy 100: 468-505.

Graham, J. R., Harvey, C. R., \& Rajgopal, S. 2005. "The economic implications of corporate financial reporting" Journal of Accounting and Economics 40: 3-73.

Hassell, J. and R. Jennings. 1986. "Relative Forecast Accuracy and the Timing of Earnings Forecast Announcement" The Accounting Review 61(January): 58-75.

Healy, P. M. and Palepu, K. G. 2001. "Information asymmetry, corporate disclosure, and the capital markets: A review of the empirical disclosure literature" Journal of Accounting \& Economics 31(September): 405-440.

Heckman, J. J. 1979. "Sample Selection Bias as a Specification Error" Econometrica 47: 153-161.

Hermalin, B. and M. Weisbach. 2012. "Information disclosure and corporate governance" The Journal of Finance LXVII (1): 195-233.

Holmström, B.1999. "Managerial Incentive Problems - A Dynamic Perspective” Review of Economic Studies 66: 169-182.

Hong, H., Lim, T., Stein, J.C. 2000. "Bad news travels slowly: size, analyst coverage, and the profitability of momentum strategies" Journal of Finance 55: 265-295. 
Jaggi, B. and A. Sannella. 1995. "The Association between the Accuracy of Management Earnings Forecasts and Discretionary Accounting Changes" Journal of Accounting, Auditing, and Finance 10: 1-21.

Jensen, M., and Meckling, W. 1976. "Theory of the firm: managerial behavior, agency costs and ownership structure" Journal of Financial Economics 3: 305-360.

Jung, W. S. 1997. The Accuracy of Managers' Earnings Forecasts and Relevance as Proxies for Market Expectation of Earnings. The Journal of Korean Securities Association 21: 265-293.

Kasznik, R. 1999. “On the Association between Voluntary Disclosure and Earnings anagement” Journal of Accounting Research 37(Spring): 57-81.

Kasznik, R., and B. Lev. 1995. "To warn or not to warn: Management disclosures in the face of an earnings surprise" The Accounting Review 70(1): 113-134.

Kwak, Y. M. and J. S. Choi. 2011. Earnings Management Associated with Types of CEO Turnover. Korean Accounting Review 36(2): 129-184.

Kwon, S. Y., D. H. Lee and M. H. Hwang. 2009. The Accuracy of Management Earnings forecast after Adopting Regulation Fair Disclosure. Korean Accounting Review 34(1): 107-141.

Lamont, O. A. 2002. "Macroeconomic forecasts and microeconomic forecasters" Journal of Economic Behavior \& Organization 48(3): 265-280.

Lang, M., and R. Lundholm. 1993. "Cross- Sectional Determinants of Analysts Ratings of Corporate disclosures" Journal of Accounting Research 31: 246-271.

Lang, M., and R. Lundholm. 1996. "Corporate Disclosure Policy and Analyst Behavior" The Accounting Review 71: 467-492.

Lee, A. Y., S. B. Chun, and S. S. Park. 2007. CEO Turnover and Earnings Management. Korean Accounting Review 32(2): 117-151.

Milbourn, T., Shockley, R. and Thakor, A. 2001. "Managerial career concerns and investments in information" Rand Journal of Economics 32: 334-351.

Mukherjee. 2008. "Career concerns, matching, and optimal disclosure policy" International Economic Review 49(4): 1211-1225.

Nagar, V. 1999. "The role of the manager's human capital in discretionary disclosure" Journal of Accounting Research 37: 167-181.

Nagar, V., Nanda, D., and Wysocki, P. 2003. "Discretionary disclosure and stock-based incentives" Journal of Accounting and Economics 34: 283-309.

Noe, C. 1999. "Voluntary disclosures and insider transactions" Journal of Accounting and Economics 27(3): 305327.

O, O. R., Y. K. Lee and K. T. Kong. 2010. The Effects of CEO Turnover and Corporate Ownership Structure on the Value Relevance of Accounting Information. Journal of Taxation and Accounting. 11(4): 305-322.

Paek, W. S., and K. Choi. 1998. An Empirical Research on Earnings Manipulation of Window Dressing Settlement Firms. Korean Accounting Review 23(2): 133-161.

Park, J. S. and J. H. Nam. 2010. Management Earnings Forecasts and Earnings Management. DAEHAN Journal of Business 23(1): 487-510.

Penman, S. 1980. "An Empirical Investigation of the Voluntary Disclosure of Corporate Earnings Forecasts" Journal of Accounting Research 18(Spring):132-160.

Penman, S. 1996. "The Articulation of Price-Earnings Ratios and Market-to-Book Ratios and the Evaluation of Growth" Journal of Accounting Research 34(Autumn): 235-259.

Pourciau, S. 1993. "Earnings management and nonroutine executive changes" Journal of Accounting and Economics 16(1-3): 317-336.

Rogers, J. L., and P. C. Stocken. 2005. "Credibility of Management Forecasts" The Accounting Review 80: 1233 1260.

Rogers, J., and A. Bushirk. 2008. "Bundled forecasts and selective disclosure of good news" Working paper. University of Chicago.

Ruland, W. 1978. "The Accuracy of Forecasts by Management and by Financial analysts" The Accounting Review 53(April): 439-447

Sam (Sunghan) Lee, Steven R. Matsunaga, and Chul W. Park. 2012. "Management Forecast Accuracy and CEO Turnover" The Accounting Review 87(November): 2095-2122. 
Shleifer, A. and Vishny, R. 1989. "Management entrenchment: The case of manager-specific investments" Journal of Financial Economics 25: 123-139.

Sohn, S. K. 1997. The Comparison of Management's Forecast with Analysts' Forecast - In case of Investor Relations. Korean Accounting Review 22 (3): 107-129.

Sohn, S. K. 1997. An Information Content Study of the Management's Forecast. Korean Accounting Review 22 (4): 159-161.

Song, Fenghua, and Anjan V. Thakor. 2006. "Information control, career concerns, and corporate governance" Journal of Finance 61: 1845-1896.

Subramanyam K.R. 1996. "The pricing of discretionary accruals" Journal of Accounting and Economics 22: 249281.

Trueman, B. 1986. "Why Do Managers Voluntarily Release Earnings Forecast?" Journal of Accounting and Economics 8: 53-71.

Verrecchia, R. 1983. "Discretionary disclosure", Journal of Accounting and Economics 5: 179-194.

Verrecchia. R. E. 2001. "Essays on Disclosure" Journal of Accounting and Economics 32: 97-180.

Waymire, G. 1984. "Additional Evidence on the Information Content of Management Earnings Forecasts" Journal of Accounting Research 22: 703-718.

Waymire, G. 1986. "Additional Evidence on Accuracy of Analyst Forecasts Before and After Voluntary Management Earnings Forecasts" The Accounting review 61 (January): 129-142.

Yoon, S. S., M. K. Ahn and D. Y. Ko. 2007. The Effect of Corporate Boards and Audit Committees on Management Forecasts. Working paper.

Zhang, W. 2009. “CEO tenure and Earnings Quality”, Working paper. University of Texas at Dallas. 


\section{NOTES}

